Journal of the Indonesian Tropical Animal Agriculture (J. Indonesian Trop. Anim. Agric.) pISSN 2087-8273 eISSN 2460-6278

41(4):196-203, December 2016

DOI: $10.14710 /$ jitaa.41.4.196-203

\title{
IN VITRO EVALUATION OF CONCENTRATE FEED CONTAINING Indigofera zollingeriana IN GOAT
}

\author{
Suharlina ${ }^{1}$, D.A. Astuti ${ }^{2}$, Nahrowi ${ }^{2}$, A Jayanegara ${ }^{2}$ and L. Abdullah ${ }^{2}$ \\ ${ }^{1}$ Graduate School of Animal Nutrition and Feed Science, \\ Bogor Agricultural University, Jl. Agatis, Darmaga Campus, Bogor 16680-Indonesia \\ ${ }^{2}$ Department of Animal Nutrition and Feed Technology, Faculty of Animal Science, \\ Bogor Agricultural University, Jl. Agatis, Darmaga Campus, Bogor 16680-Indonesia \\ Corresponding E-mail: lukiabdullah@gmail.com
}

Received May 07, 2016; Accepted August 22, 2016

\begin{abstract}
ABSTRAK
Penelitian ini bertujuan untuk mengevaluasi fermentabilitas dan kecernaan nutrien pakan konsentrat berbasis Indigofera zollingeriana secara in vitro. Penelitian ini menggunakan rancangan acak kelompok pada 3 jenis pakan konsentrat dalam 4 kelompok cairan rumen yang berbeda. Pakan konsentrat yang digunakan yaitu R1, R2 dan R2 masing-masing mengandung 0, 20 dan 40\% I. zollingeriana. Peubah yang diamati antara lain kecernaan nutrien (bahan kering, bahan organik dan protein), produksi gas total, VFA parsial dan NH3. Data dianalisis menggunakan analisis ragam (ANOVA). Hasil penelitian menunjukkan bahwa nilai kecernaan bahan kering (KCBK), bahan organik (KCBO) dan protein $(\mathrm{KCPK})$ memperlihatkan pola yang sama yaitu $\mathrm{R} 2$ lebih tinggi dari $\mathrm{R} 1(\mathrm{P}<0.05)$, sedangkan R3 memiliki nilai kecernaan yang sama dengan R2 dan R1. Tidak terdapat perbedaan produksi gas total pada ketiga jenis ransum konsentrat. Konsentrasi VFA parsial masing-masing ransum konsentrat tidak berbeda nyata. Perlakuan R2 memiliki konsentrasi $\mathrm{NH}_{3}$ paling rendah $(\mathrm{P}<0.05)$ dibandingkan R1 dan R3. Dapat disimpulkan bahwa penambahan I. zollingeriana dapat digunakan sebagai penyusun pakan konsentrat maksimal $20 \%$.
\end{abstract}

Kata kunci: fermentabilitas, Indigofera zollingeriana, in vitro, pakan konsentrat

\begin{abstract}
This study was conducted to evaluate the fermentability and nutrient digestibility of concentrate feed containing Indigofera zollingeriana using in vitro technique. Randomized complete block design was used on 3 types of concentrate feed and 4 groups (replicates) of goat's rumen liquid. The concentrate feeds were R1, R2 and R3 containing I. zollingeriana at 0 (control), 20 and 40\%, respectively. Variables observed were total gas production, in vitro dry matter digestibility (IVDMD), organic matter (IVDOM), and crude protein (IVDCP), volatile fatty acid (VFA) profiles and NH3 concentration. Data were analyzed using analysis of variance (ANOVA). Results showed that there was no significant effect of R3 on IVDMD, IVDOM and IVDCP as compared to R1 and R2. However, there was significant difference $(\mathrm{P}<0.05)$ of the parameters between $\mathrm{R} 1$ and $\mathrm{R} 2(\mathrm{P}<0.05)$. There was no significant effect $(\mathrm{P}<0.05)$ of different Indigofera levels on total gas production. The partial VFA of each concentrate feeds was not significantly different, but the percentage of acetic acids of concentrates containing I. zollingeriana were higher than those of control $(\mathrm{P}<0.05)$. The concentration of rumen $\mathrm{NH}_{3}$ of $\mathrm{R} 2$ was lower than $\mathrm{R} 1$ and $\mathrm{R} 3$ $(\mathrm{P}<0.05)$ even though the IVCPD of R2 was higher than R1. It could be concluded that the inclusion of I. zollingeriana as concentrate feed ingredient at $20 \%$ maximum level .
\end{abstract}

Keywords: fermentability, Indigofera zollingeriana, in vitro, concentrate feed 


\section{INTRODUCTION}

Ruminant have an important contribution in the provision of foods, especially milk and meat. Ruminants account for almost all of the milk and about one-third of the meat production worldwide (FAO, 2004). Even though milk and its product are dominated by dairy cow, goat milk is believed to have several advantages over cow's milk in several countries including Indonesia. The dairy goat farm in Indonesia is dominated by smallholder farmers. Poor quality feed such as tropical grasses given by small-holder farmers lead to low milk production. Feeding tropical grasses as the main source of feeds is not sufficient to meet the nutritional requirement of high-producing dairy goats (Fujisaka et al., 2000), due to the tropical grasses are high of fiber content, and relatively low ranging of protein contents about 4-9 \%DM, while the protein requirement of dairy goat feed reaches up to $18 \% \mathrm{DM}$.

Productivity of goats in tropical areas could be improved by introducing forage legumes, such as Leucaena leucocephala, Gliricidia sepium or Flemingia macrophylla that rich in protein (Ondiek et al., 2000; Mui et al., 2002; Fagundes et al., 2014), especially during the dry season when forages quality becomes poor. Another potential legume that can be used as feed for dairy goats is a forage namely Indigofera zollingeriana. The plant has a rapid regrowth in the defoliation interval of 60 days with a production of 51 tons/ha/year (Abdullah, 2010). I. zollingeriana is very adaptive to low soil fertility, easy on maintenance and low prize, and high seed production potential throughout the season (Abdullah and Suharlina, 2010). The branch base and shoot tip of $I$. zollingeriana that harvested at 68 days defoliation time containing of $20.96 \%$ and $23.40 \% \mathrm{DM}$ crude protein (CP), $21.20 \%$ and $14.60 \% \mathrm{DM}$ crude fiber (CF), $49.41 \%$ and $56.10 \%$ DM neutral detergent fiber (NDF), $26.23 \%$ and $30.73 \% \mathrm{DM}$ acid detergent fiber (ADF) and the in vitro digestibility of $69.17 \%$ and $78.58 \% \mathrm{DM}$ dry matter (IVDMD) and $70.79 \%$ and $77.63 \% \mathrm{DM}$ organic matter (IVOMD), respectively (Abdullah and Suharlina, 2010). Suharlina and Abdullah (2010) reported that $I$. zollingeriana forage (leaves and twigs) treated by liquid organic fertilizer $0-40 \%$ containing $24.42-31.05 \% \mathrm{DM}$ of $\mathrm{CP} ; 50.51-51.77 \% \mathrm{DM}$ of NDF; $48.19-49.15 \% \mathrm{DM}$ of ADF; 68.21-73.73.15\%DM, respectively. The use of fresh $I$. zollingeriana for local goats increased daily weight gain and feed efficiency up to $45 \%$ and $30 \%$, respectively (Tarigan and Ginting, 2011). Further, an experiment using pure pellet of $I$. zollingeriana leaves increased goat milk production, feed efficiency and nutrient efficiency by approximately $26 \%, 15-23 \%$ and 5 $9 \%$, respectively (Abdullah et al., 2012).

This study was carried out to evaluate the fermentability and nutrient digestibility of concentrate feed containing I. zollingeriana in goat using in vitro technique.

\section{MATERIALS AND METHODS}

This study was conducted in the Laboratory of Dairy Nutrition, Faculty of Animal Science, Bogor Agricultural University. Leaves and twigs of I. zollingeriana were collected from University Farm Research Station, Darmaga, Bogor Agricultural University, Indonesia. The samples were obtained from three plots with the dimension of $4 \times 6 \mathrm{~m}$ each. Each plot consisted of $I$. zollingeriana plants with the planting dimension of $1 \times 1.5 \mathrm{~m}$. After 68 days of planting period as recommended from our previous study (Abdullah and Suharlina, 2010) the plants were harvested and leaf and twig samples were collected. Leaves and twigs of I. zollingeriana were air-dried and then oven-dried at $60^{\circ} \mathrm{C}$ for $24 \mathrm{~h}$. I. zoliner forage was formulated in feed as R1, R2 and R3 with varying levels, i.e. 0,20 and $40 \%$ (DM basis), respectively (Table 1 ). The feed materials were ground to pass a $1 \mathrm{~mm}$ sieve size and mixed homogeneously. Dry matter (DM), ash, crude protein $(\mathrm{CP})$, extract ether and crude fiber (CF) composition of each cooncentrate feed were determined by proximate analysis (AOAC, 1995; Table 2).

Randomized complete block design was employed on 3 types of feeds and 4 groups of rumen liquid using in vitro technique. The in vitro method was based on Tilley and Terry (1963), the rumen fluid was collected from slaughter goats shortly after goat slaughtered at morning time. Rumen fluid was filtered through $100 \mu \mathrm{m}$ nylon sieve size. An amount $0.5 \mathrm{~g}$ DM samples were filled up into fermentor tube and added by $40 \mathrm{ml}$ McDougall solutions and $10 \mathrm{ml}$ rumen fluid. The fermentor tubes were put into the shaker bath with $39^{\circ} \mathrm{C}$ temperature and flowed with $\mathrm{CO}_{2}$ for 30 seconds, the $\mathrm{pH}$ was checked (6.5 up to 6.9), and then covered by ventilated rubber cap. The incubation was conducted during 48 hours. After 48 hours the rubber cap of tubes were open up and 
Table 1. Formulation of Experimental Concentrate Feed

\begin{tabular}{|c|c|c|c|}
\hline \multirow{2}{*}{ Ingredients } & $\mathrm{R} 1$ & $\mathrm{R} 2$ & R3 \\
\hline & \multicolumn{3}{|c|}{------- \% DM ------- } \\
\hline Tapioca pulp & 24 & 13 & 12 \\
\hline Corn & 9 & 9 & 9 \\
\hline Coconut cake & 35 & 39 & 20 \\
\hline Indigofera zollingeriana & 0 & 20 & 40 \\
\hline Rice bran & 28 & 15 & 15 \\
\hline Molases & 1 & 1 & 1 \\
\hline Premix & 1 & 1 & 1 \\
\hline $\mathrm{CaCO}_{3}$ & 1 & 1 & 1 \\
\hline DCP & 0.5 & 0.5 & 0.5 \\
\hline $\mathrm{NaCl}$ & 0.5 & 0.5 & 0.5 \\
\hline
\end{tabular}

$\mathrm{R} 1$, concentrate feed without $I$. zollingeriana (control); R2, concentrate feed containing $20 \% \mathrm{DM}$ I. zollingeriana; R3, concentrate feed containing $40 \%$ DM I. zollingeriana.

Table 2. Nutrient Contents of Experimental Concentrate Feed (\%DM)

\begin{tabular}{llllllll}
\hline & Ash & EE & CP & CF & NFE & Ca & P \\
\hline R1 & 11.4 & 8.82 & 14.0 & 10.5 & 55.3 & 1.47 & 0.27 \\
R2 & 11.5 & 8.92 & 16.0 & 10.6 & 53.0 & 0.79 & 0.27 \\
R3 & 12.0 & 9.33 & 17.2 & 11.1 & 50.4 & 2.14 & 0.31 \\
\hline
\end{tabular}

$\mathrm{R} 1$, concentrate feed without $I$. zollingeriana (control); R2, concentrate feed containing 20\% DM I. zollingeriana; $\mathrm{R} 3$, concentrate feed containing 40\% DM I. zollingeriana.

added by $4 \mathrm{ml} \mathrm{HgCl}_{2}$ with $5 \%$ concentration to stop the microbial activity, and subsequently centrifuged at $4000 \mathrm{rpm}$ of speed for 15 minutes. The residual substrates are separated into sludge at the bottom and the clear supernatant is at the top. The residues were added by $50 \mathrm{ml}$ solution of pepsin- $\mathrm{HCl} 0.2 \%$ and then incubated for 48 hours without a rubber cap. After 48 hours the tubes were centrifuged at $4000 \mathrm{rpm}$ of speed for 15 minutes. The residues were filtered through Whatman paper No. 41 using vacuum pump, and the destillate residues were put in to a porcelain cup. The crude protein of residue obtained by Kjeldal metod (AOAC, 1995), while the dry matter obtained by drying in oven at $105^{\circ} \mathrm{C}$ temperature for 8 hours. Subsequently, the residues were burnt to ashes using using oven at $450-600^{\circ} \mathrm{C}$ temperature for 6 hours to determin the organic matter. The residual substrates of the incubation without sample of feed materials were used as a blank. The in vitro digestibility nutrients calculated by these formulas:

$$
\begin{aligned}
& \operatorname{IVDMD}(\%)=\frac{\text { DM sample }(\mathrm{g})-\text { DM residue }(\mathrm{g})-\text { DM Blank }(\mathrm{g})}{\text { DM sample }(\mathrm{g})} \times 100 \% \\
& \operatorname{IVOMD}(\%)=\frac{\text { OM sample }(\mathrm{g})-\text { OM residue }(\mathrm{g})-\text { OM Blank }(\mathrm{g})}{\text { OM sample }(\mathrm{g})} \times 100 \% \\
& \operatorname{IVCPD}(\%)=\frac{\text { CP sample }(\mathrm{g})-\text { CP residue }(\mathrm{g})-\text { OM Blank }(\mathrm{g})}{\text { CP sample }(\mathrm{g})} \times 100 \%
\end{aligned}
$$

Where

IVDMD : in vitro dry matter digestibility

IVOMD : in vitro organic matter digestibilty

IVCPD : in vitro crude protein digestibilty

DM : Dry matter

OM : Organic matter

CP : Crude protein

The gas production method was based on Blümmel et al., (1997). Rumen fluid was collected from slaughter goats shortly after goat slaughtered at morning time. Rumen fluid was filtered through $100 \mu \mathrm{m}$ nylon sieve size and added by buffer being reduced. Rumen-buffer was saturated with $\mathrm{CO}_{2}$ for 10 minutes before being inserted into the syringe glass to ensure anaerobic conditions in the reaction. An amount of $380 \mathrm{mg}$ DM samples were inserted into the syringe and closed with a piston that has been lubricated by vaseline. As much as $30 \mathrm{ml}$ of buffered-rumen fluid inserted into each syringe through the inlet channel, and then the syringe immediately put in a water bath at $39^{\circ} \mathrm{C}$ temperature. Gas production was observed at $0,3,6,9,12$ and 24 after incubation.

Volatile fatty acids (VFA) were determined by the supernatant which incubation for 4 hours using gas chromatography, while $\mathrm{NH}_{3}$ concentration was based on Conway diffusion method. The concentration of $\mathrm{NH}_{3}$ was measured using a micro diffusion Conway method (Department of Dairy Science, 1966). A Conway plate and its cap were given by vaseline the edges of the cups, and then about $1 \mathrm{ml}$ of the supernatant was put on one side of the bulkhead plate and on the other position was put $1 \mathrm{ml}$ 
solution of saturated $\mathrm{Na}_{2} \mathrm{CO}_{3}$. The plates were placed at an angle towards the bulkhead so that they were not mixed before the plate was sealed. At the center of the plate was put $1 \mathrm{ml}$ of boric acid indicator solution, and then the plate was sealed. The plates were shake until $\mathrm{Na}_{2} \mathrm{CO}_{3}$ and supernatant mixed. Ammonia that released from the reaction will be captured by boric acid shown by a color change. After 24 hours, boric acid was titrated by $0.0059 \mathrm{~N} \mathrm{H}_{2} \mathrm{SO}_{4}$ solution until the color changes return to the original color. The concentration of $\mathrm{NH}_{3}$ measured by followed this formula:

$\mathrm{NH}_{3}(\mathrm{mM})=\frac{\mathrm{ml} \mathrm{H}_{2} \mathrm{SO}_{4} \times \mathrm{N} \mathrm{H}_{2} \mathrm{SO}_{4} \times 1000 / 1}{\text { gram sample } \times \text { DM sample }}$

The data were analyzed using analysis of variance (ANOVA). If there were significant differences among treatments at $\mathrm{P}<0.05$, the analysis was continued with Least Significance Difference (LSD) test.

\section{RESULTS AND DISCUSSION}

Higher inclusion levels of Indigofera increased CP contents of the experimental concentrates feed (Table 2). This was due to the high CP content of the plant (29.2\% DM). High $\mathrm{CP}$ of Indigofera had been also reported by some authors and generally ranged from 23-27\% DM (Kaitho et al., 1998; Tscherning et al., 2006; Bhatta et al., 2012; Bhatta et al., 2013). In vitro dry matter (IVDMD) and organic matter digestibility (IVOMD) values of the experimental concentrates were $65.5-71.5 \%$ and $63.0-68.1 \%$, respectively, while the in vitro crude protein digestibility (IVCPD) values were 79.1-83.8\% (Figure 1). The IVDMD, IVOMD and IVCPD values had similar trends in which $\mathrm{R} 2$ were higher than R1 $(\mathrm{P}<0.01)$, while R3 had similar value with R1 and R2 feeds. The in vitro digestibility of I. zollingeria had been reported by Suharlina and Abdullah (2010) ranged about 68.21$73.73 .15 \% \mathrm{DM}$ of IVDMD; $65.33-70.64 \% \mathrm{DM}$ of IVOMD and $87.50-90.64 \% \mathrm{DM}$ of IVCPD (in vitro crude protein digestibility), respectively. It was shown that the inclusion level of $I$. zollingeriana in feed by $20 \%$ improved the nutrient digestibility of R2 since the plant is characterized by its high protein and low fiber contents thus increase its digestibility (Suharlina et al., 2016). The nutrient digestibility value of R3 was not different with that of R1 despite it contains I. zollingeriana higher than R1. Apparently higher fiber and lower NFE contents found in R3 than that found in R1 are among the plausible factors behind such response.

The digestibility of dry matter and organic matter are a primary determinant of the quality of feed and forage. Nutrient digestibility is determined by the composition of the fiber in the diet. Control concentrate feed (R1) contained high level of fiber and low level of protein. These

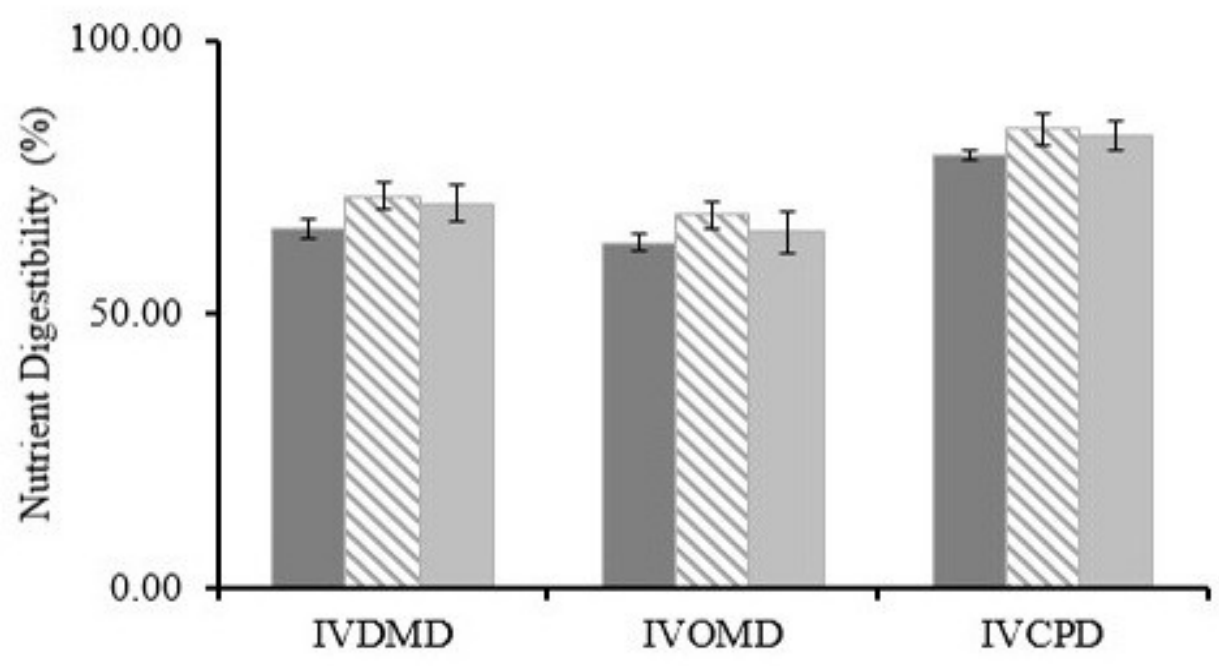

Figure 1. Nutrient Digestibility of Experimental Concentrate Feed. Error bars indicate standard error values for the concentrates feed.

( DM 1 . zollingeriana; ( $\left.{ }^{\prime}\right) \mathrm{R} 3$, concentrate feed containing $40 \% \mathrm{DM} I$. zollingeriana. 
concomitantly high fiber and low protein have been observed to be negatively correlated with digestibility coefficients in sheep, goat, cattle and buffalo (Riaz et al., 2014). It is widely known that protein is more digestible as compared to fiber by rumen microbes. Although R3 had the highest inclusion level of I. zollingeriana than the other concentrate, it showed similar digestibility values to R1. It seems that secondary compounds present in I. zollingeriana such as tannins and saponins influence the digestibility by protecting protein and other nutrients from microbial degradation and fermentation in the rumen (Jayanegara et al., 2009; Jayanegara et al., 2014). It was analyzed that I. zollingeriana used in the present experiment contained $2.9 \mathrm{~g} / \mathrm{kg}$ DM tannins and $2.6 \mathrm{mg} / \mathrm{kg}$ DM saponins.

The total gas production value describe the efectiveness of the fermentation process. The total gas production of each concentrate feed had similar values at any time of measurements (Figure 2). The values of total gas production of $\mathrm{R} 1, \mathrm{R} 2$, and R3 were $22.92 \pm 1.09,24.83 \pm 4.42$, and $20.31 \pm 4.22 \mathrm{ml} / \mathrm{mg} \mathrm{DM}$, respectively. This indicated that all of the concentrates had similar in vitro fermentability values. There were no differences on total gas production in this study due to the concentrates feed have the similar crude fiber content (Table 2). Fiber fraction is a limitating factor on in vitro fermentation (Ndlovu and Nherera, 1997). The output of the carbohydrate fermentation is the volatile fatty acids (VFA) which is a source of energy for animals. The main component of VFA are acetic acid, propionic acid, butyric acid, and small amount of valeric acid. The partial VFA concentrations of each concentrates feed were not significantly different (Table 3), apparently because of each concentrate had similar proportions of nitrogen free extract (NFE). The inclusion of I. zollingeriana forage did not change the characteristics of concentrate. Therefore, $I$. zollingeriana forage can be used as a source of concentrate originally from forage. Acetic acid is required as a precursor of milk fat, therefore, the higher of acetate-propionat $(\mathrm{A}: \mathrm{P})$ ratio indicated ideal ration for dairy animals. Both acetate and propionate are required for milk production in dairy animals such us dairy cows and dairy goats; acetate is important for milk fat synthesis,

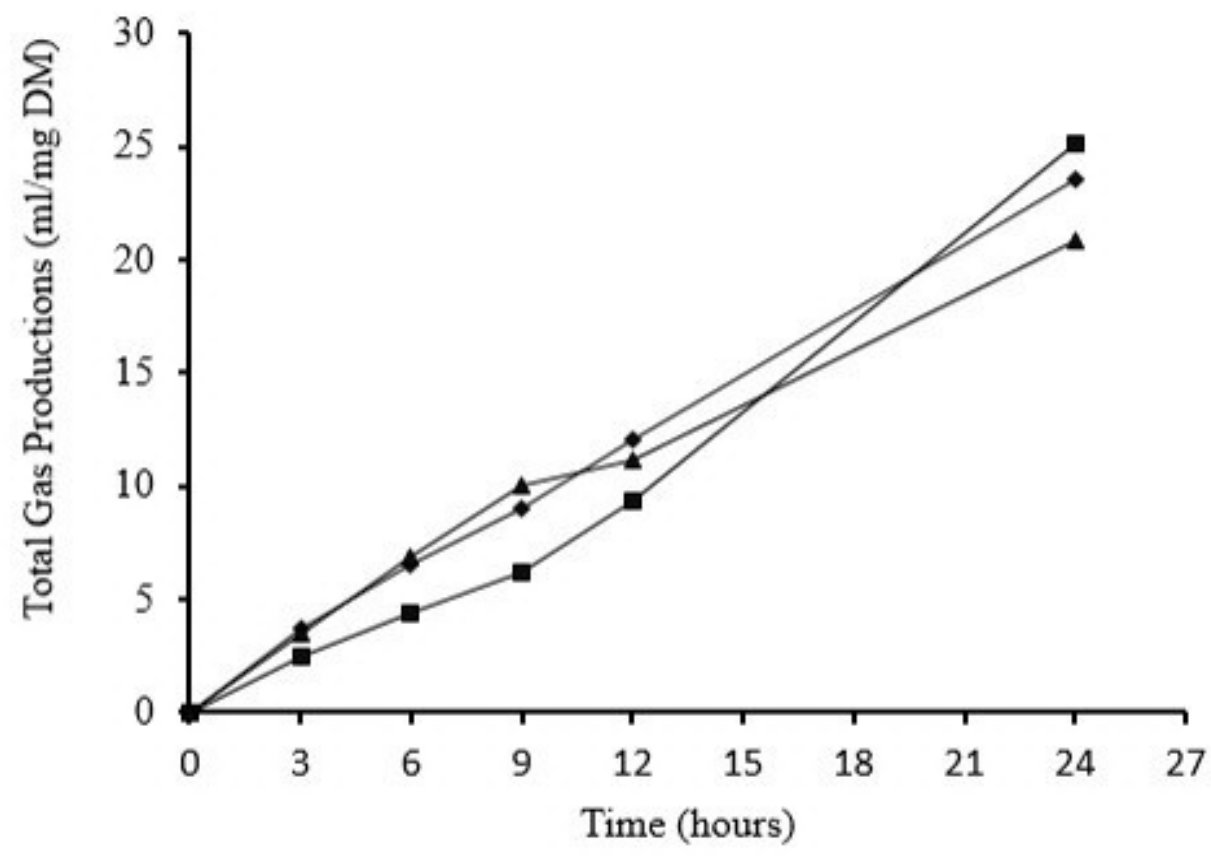

Figure 2. Effect of Different Levels of Indigofera in Experimental Concentrate Feed on Total Gas Production.

$\mathrm{R} 1$, concentrate feed without $I$. zollingeriana (control);

$\mathrm{R} 2$, concentrate feed containing $20 \% \mathrm{DM} I$. zollingeriana;

$\mathrm{R} 3$, concentrate feed containing $40 \% \mathrm{DM} I$. zollingeriana. 
Table 3. The Partial VFA and NH3 Concentration of Experimental Concentrate Feed

\begin{tabular}{lccc}
\hline \multicolumn{1}{c}{ VFA Partial $(\mathrm{mM})$} & $\mathrm{R} 1$ & $\mathrm{R} 2$ & $\mathrm{R} 3$ \\
\hline Acetic acid & $13.6 \pm 1.5$ & $13.6 \pm 0.6$ & $14.4 \pm 0.3$ \\
Propionic acid & $4.40 \pm 0.4$ & $3.76 \pm 0.1$ & $4.40 \pm 0.4$ \\
Butyric acid & $1.41 \pm 0.4$ & $1.42 \pm 0.2$ & $1.44 \pm 0.4$ \\
Iso-butyric acid & $0.95 \pm 0.1$ & $1.02 \pm 0.2$ & $1.02 \pm 0.1$ \\
n-Valeric acid & $0.34 \pm 0.1$ & $0.34 \pm 0.1$ & $0.33 \pm 0.1$ \\
n-Caproic acid & $0.09 \pm 0.03$ & $0.09 \pm 0.03$ & $0.04 \pm 0.07$ \\
A-P ratio & $3.08 \pm 0.08^{\mathrm{b}}$ & $3.62 \pm 0.27^{\mathrm{a}}$ & $3.27 \pm 0.29^{\mathrm{ab}}$ \\
$\mathrm{NH}_{3}(\mathrm{mM})$ & $4.21 \pm 0.1^{\mathrm{b}}$ & $3.87 \pm 0.1^{\mathrm{c}}$ & $5.23 \pm 0.2^{\mathrm{a}}$ \\
\hline
\end{tabular}

a,b,c Within rows, means followed by different superscripts are different at $P<0.05$; A-P ratio: Acetic acid Propionic acid ratio; R1, concentrate feed without I. zollingeriana (control); R2, concentrate feed containing $20 \%$ DM I. zollingeriana; R3, concentrate feed containing 40\% DM I. zollingeriana.

whereas propionate is required for milk production (Sutton et al., 2003; Serment et al., 2011). The A:P ratio of $\mathrm{R} 1, \mathrm{R} 2$ and $\mathrm{R} 3$ in this study were $3.08,3.62$, and 3.29 , respectively. The A:P ratio of $\mathrm{R} 2$ was higher $(\mathrm{P}<0.05)$ than $\mathrm{R} 1$, while R3 had similar value with R1 and R2. The lower of A:P ratio on $\mathrm{R} 1$ due to the absence of forage such as I. zollingeriana. The fermentation of forages in ruminal system is produce more acetate than propionate. The inclusion of $I$. zollingeriana increased $\mathrm{A}: \mathrm{P}$ ratio on $\mathrm{R} 2$. The $\mathrm{R} 3$ concentrate showed similar A:P ratio to other concentrates, although it had the highest inclusion level of $I$. zollingerina. It caused that $I$. zollingeriana contain secondary compound such us tannins and saponins which may affect the process of fermentation in the rumen. These substances may negativelly influence digestion processes in ruminants by acting as antinutritional factors when present at high concentration, but low to moderate concentration of these compounds are desirable in order to positively modulate rumen fermentation for higher anaimal productivity and lower environmental pollution (Suharlina et al., 2016). The concentrations of rumen $\mathrm{NH}_{3}$ of each concentrates feed showed significantly differences $(\mathrm{P}<0.05)$. The concentration of rumen $\mathrm{NH}_{3}$ of $\mathrm{R} 2$ was lower than R1 and R3 $(\mathrm{P}<0.05)$ even though the IVCPD of R2 was higher than R1. The lower concentration of rumen $\mathrm{NH}_{3}$ of $\mathrm{R} 2$ could have been due to the rapid utilization of nitrogenous compound released from the legume by rumen microbes in the presence of available energy and other nutrients (Khandaker et al., 1998). Furthermore, the presence of tannins in the plant may also contribute to such lower rumen $\mathrm{NH}_{3}$ as has been proven by a meta-analysis study conducted by Jayanegara and Palupi (2010).

\section{CONCLUSION}

The concentrate feed containing $20 \%$ of $I$. zollingeriana (R2) showed the highest in vitro dry and organic matter, and crude protein digestibility values in goat. It could be concluded that the inclusion of $I$. zollingeriana as concentrate feed ingredient at $20 \%$ maximum level.

\section{REFERENCES}

Abdullah, L. 2010. Herbage production and quality of Indigofera treated by different concentration of foliar fertilizer. Med. Pet. 33:169-175.

Abdullah, L., and Suharlina. 2010. Herbage yield and quality of two vegetative parts of Indigofera at different time of first regrowth defoliation. Med. Pet. 33:44-49.

Abdullah, L., T. Apdini, and D.A. Astuti. 2012. Use of Indigofera zollingeriana as a forage protein source in dairy goat rations. Proceedings of the 1st Asia Dairy Goat Confetrence, Kuala Lumpur, 9-12 April 2012, pp. 72-74.

AOAC. 1995. Official Methods of Analysis. $16^{\text {th }}$ 
ed. Association of Official Analytical Chemists, Washington DC, USA.

Bhatta R., M. Saravanan, L. Baruah, and K.T. Sampath. 2012. Nutrient content, in vitro ruminal fermentation characteristics and methane reduction potential of tropical tannin-containing leaves. J. Sci. Food Agric. 92:2929-2935.

Bhatta R., M. Saravanan, L. Baruah, K.T. Sampath, and C.S. Prasad. 2013. Effect of plant secondary compounds on in vitro methane, ammonia production and ruminal protozoa population. J. Appl. Microbiol. 115:455-465.

Blümmel, M., H.P.S. Makkar, and K. Becker. 1997. In vitro gas production: A technique revisited. J. Anim. Physiol. Anim. Nutr. 77:24-34.

Department of Dairy Science. 1966. General Laboratory Procedures. University of Wisconsin, Madison.

Fagundes, G.M., E.C. Modesto, C.E.M. Fonseca, H.R.P. Lima, and J.P. Muir. 2014. Intake, digestibility and milk yield in goats fed Flemingia macrophylla with or without polyethylene glycol. Small Rum Res. 116:88-93.

FAO. 2004. Food and Agriculture Organization. FAOSTAT Data. Rome, Italy.

Fujisaka, S., I.K. Rika, T.M. Ibrahim, L.V. An. 2000. Forage tree adoption and use in Asia. In: W.W. Stur, P.M. Horne, J.B. Hacker, P.C. Kerridge (Eds.). Working with Farmers: The Key to Adoption of Forage Technologies. ACIAR Proceedings No. 95:243-253.

Jayanegara, A., and E. Palupi. 2010. Condensed tannin effects on nitrogen digestion in ruminants: a meta-analysis from in vitro and in vivo studies. Med. Pet. 33:176-181.

Jayanegara, A., E. Wina, and J. Takahashi. 2014. Meta-analysis on methane mitigating properties of saponin-rich sources in the rumen: influence of addition levels and plant sources. Asian-Australas. J. Anim. Sci. 27:1426-1435.

Jayanegara, A., H.P.S. Makkar, and K. Becker. 2009. Emisi metana dan fermentasi rumen in vitro ransum hay yang mengandung tanin murni pada konsentrasi rendah. Med. Pet. 32:184-194.

Kaitho, R.J., I.V. Nsahlai, B.A. Williams, N.N. Umunna, S. Tamminga, and J. Van Bruchem. 1998. Relationships between preference, rumen degradability, gas production and chemical composition of browses. Agrofor. Syst. 39:129-144.

Khandaker, Z.H., H. Steingass, and W. Drochner. 1998. Supplementation of wheat straw with sesbania on voluntary intake, digestibility and ruminal fermentation in sheep. Small Rum. Res. 28:23-29.

Mui, N.T., I. Ledin, P. Uden, and D. Van Binh. 2002. The foliage of flemingia (Flemingia macrophylla) or jackfruit (Artocarpus heterophyllus) as a substitute for a rice bransoya bean concentrate in the diet of lactating goats. Asian Australas J Anim Sci. 15:45-54.

Ndlovu, L.R., and F.V. Nherera. 1997. Chemical composition and relationship to in vitro gas production of Zimbabwean browable indigenous tree species. Anim. Feed Sci and Technol. 69:121-129.

Ondiek, J.O., J.K. Tuitoek, S.A. Abdulrazak, F.B. Bareeba, and T. Fujihara. 2000. Use of Leucaena leucocephala and Gliricidia sepium as nitrogen sources in supplementary concentrates for dairy goats offered Rhodes grass hay. Asian Australas J Anim Sci. 13: 1249-1254.

Riaz, M.Q., K.H. Sudekum, M. Clauss, and A. Jayanegara. 2014. Voluntary feed intake and digestibility of four domestic ruminant species as influenced by dietary constituents: a meta-analysis. Livest. Sci. 162:76-85.

Serment, A., P. Schmidely, S. Giger-Reverdin, P. Chapoutot, and D. Sauvant. 2011. Effect of the percentage of concentrate on rumen fermentation, nutrient digestibility, plasma metabolites and milk composition in midlactation goats. J. Dairy Sci. 94:3960-3972.

Suharlina, and L. Abdullah. 2010. Productivity improvement of Indigofera sp. as high quality forages using liquid organic fertilizer: The effect on nutritional content. Proceeding of National Seminar of Tropical Forages. Denpasar, 5th November 2010.

Suharlina, D.A. Astuti, Nahrowi, A. Jayanegara and L. Abdullah. 2016. Nutritional evaluation of dairy goat rations containing Indigofera zollingeriana by using in vitro Rumen Fermentation Technique (RUSITEC). Int. J. Dairy Sci. 11:100-105.

Sutton, J.D., M.S. Dhanoa, S.V. Morant, J. France, D.J. Napper, and E. Schuller, 2003. Rates of production of acetate, propionate and butyrate in the rumen of lactating dairy cows given normal and low-rouhage diets. J. Dairy Sci. 86:3620-3633. 
Tarigan, A., and S.P. Ginting. 2011. Effects of inclusion levels of Indigofera sp. on feed intake, digestibility, and body weight gain in kids fed Brachiaria ruziziensis. JITV. 16:2532.

Tilley, J.M.A., and R.A. Terry. 1963. A two stage technique for the in vitro digestion of forage crops. J Brit. Grass. Soc. 18:104-111.
Tscherning, K., C. Lascano, E. Barrios, R. Schultze-Kraft, and M. Peters. 2006. The effect of mixing prunings of two tropical shrub legumes (Calliandra houstoniana and Indigofera zollingeriana) with contrasting quality on $\mathrm{N}$ release in the soil and apparent $\mathrm{N}$ degradation in the rumen. Plant Soil 280:357-368 